\title{
A Late Pliocene Baby Stegodon cf. Stegodon insignis (Proboscidea) from Upper Siwalik of Samba District, Jammu and Kashmir, India
}

\author{
Som Nath Kundal, Gyan Bhadar and Sandeep Kumar \\ Department of Geology, University of Jammu, Jammu-180006, India \\ E-mail: somnath.kundal@gmail.com
}

\begin{abstract}
One complete molar of a baby Stegodon is reported from the road-cutting section of the mudstone horizon of Nagrota Formation exposed about $2 \mathrm{~km}$ south of Labli village. The molar yielding horizon underlies geochronologically dated (2.48 ma) volcanic ash bed which is the extension of Barakheter-Uttarbaini ash bed in the Uttarbaini Formation (Nagrota Formation/ Pinjor Formation), Upper Siwalik Subgroup, Samba district, Jammu \& Kashmir, India. Based on the molar morphological parameters, the specimens have been identified and tentatively referred to Stegodon cf. Stegodon insignis (a baby Stegodon). A brief about the age, migration and distribution of Stegodon is also discussed in the present paper.
\end{abstract}

Keywords: Late Pliocene, Stegodon cf. Stegodon insignis, Upper Siwalik, Samba District, Jammu and Kashmir, India

\section{INTRODUCTION}

The extinct subfamily Stegodontinae of Proboscidea comprises of two genera namely Steglophodon (blunter ridges with rounded conules) and Stegodon (hoofed roofed with compressed teetiform ridges). Fossils of both the Steglophodon and Stegodon have been recovered in India. Stegodon has an intermediate position between mastodonts and typical elephants (Falconer, 1857) and is represented by the following species in Indian subcontinent: Stegodon insignis, S. ganesa, S. bombifrons, S. elephantoides (=S. cliftii), S. pinjorensis, S. katliensis, S. zdanskyi, S. officinalis, S. bondolensis, S. aurorae, S. airawana, S. trigonoephalus, S. orientlisn, S. sinensis, S. orientlis shodoensis, $S$. trigonoeephalus praceursor. The detailed work on the geological, palaeontological, ecological implications, taxonomy, diet, migration, distribution and phylogentic studies on Stegodon in Indian subcontinent has been carried out by number of workers (Sahni and Khan, 1961; Hooijar, 1955, 1964; Chakravarti,1965; Aguirre, 1969; Moglio, 1973; Badam, 1973; Badam and Sharma, 1973; Tobien, 1977; Nanda, 1980; Badam and Salahuddin, 1982; Badam and Kumar, 1982; Joshi et al., 1982; Ann, 1985; Nanda, 1988; Arif and Hussain, 1992; Lamba, 1993; Nanda and Corvinus, 2000; Rai, 2004; Samiullah et al., 2014; Nanda, 2015 ).

The Siwalik of Jammu lies in an intermediate position between the Potwar Plateau in the west and the Himachal Pradesh in the east. A number of workers have recorded and 
studied the Proboscidean fauna of Jammu Siwaliks (Wadia, 1925; Ganjoo,1985; Ganjoo, 1992; Verma et al. 2002; Kundal and Kundal, 2011; Kundal et al., 2017). Wadia (1925) recovered a tusk of Stegodon ganesa having length of about 11 feet 5 inch from Nagrota Formation, Upper Siwalik Subgroup exposed near the village Jagti in Jammu district. Ganjoo (1985) recovered dental remains of Stegolophodon sp., Stegodon insignis-ganesa and Elephas sp. from the Pleistocene deposits near village Kirli, Rajpul and Dewan of Khanpur Formation (Pinjor Formation) and Tawi Formation (Boulder Formation) of Upper Siwalik Subgroup of Jammu region.

Further, Ganjoo (1992) recovered molars of Stegolophodon sp. and Stegodon sp. from the section very near to Jagti in the Pinjor Formation of Upper Siwalik of Jammu and gave their ecological implications. Recently Kundal and Kundal (2011) recovered a molar of Elephas cf. Elephas maximus indicus from the post-Siwalik deposits of Jammu. A good number of specimens (Steglophodon species, Stegodon bombifrons, Stegodon sp., Stegodon insignis, Stegodon ganesa, Elephas planifrons, Elephas hysudricus) collected from Nagrota Formation (= Pinjor Formation) of Jammu Siwalik by Geological Survey of India Scientists and have been recorded by Verma et al. (2002). A good number of probscidean specimens has been described in the WIHG monograph series, number 2 (Nanda, 2015). Very recently Kundal et al. (2017) recovered a third molar of Elephas cf. Elephas planifrons from the mudstone horizon immediately underlying the geochronologically dated volcanic ash bed exposed at Nangal village which is the extension of Barakhetar ash beds in the Nagrota Formation (= Pinjor Formation) of Upper Siwalik Subgroup of the Jammu province, J\&K, India and extended its range zone. A good number of species of microfossils (ostracodes, gastropods) and microvertebrates have also recovered from the same horizon (Prasad et al., 2005; Bhat et al., 2008; Bhandari and Kundal, 2008; Kundal and Prasad, 2011; Kundal, 2013; Kundal, 2015).

In the present study, a complete molar of Stegodon cf. Stegodon insignis (baby) of Late Pliocene age recovered from the mudstone horizon underlying the geochronological dated (2.48 my) bentonitized tuff band exposed at Anandpur village about $2 \mathrm{~km}$ south of Labli village and $1.5 \mathrm{~km}$ east of Uttarbaini ash bed, Upper Siwalik of Samba District has been described (Fig.1). A brief about age, migration and distribution of the Stegodon is also discussed in the present paper.

Siwalik rocks occupy the southern margin of Himalaya separated from lesser Himalaya by Main Boundary Thrust (MBT) in the north whereas Himalayan Frontal Fault (HFF) in the south separates it from Indo-Gangetic plains. The Siwalik succession is thicker in northwestern part (Pakistan) and thinner towards northeast (India and Nepal). The average thickness is about 5-6 km. All the type sections of the Siwaliks are in the Pakistan except one namely Pinjor in India. Stratigraphically, the Siwalik Group is classified into three Subgroups and seven Formations viz. Lower Siwalik Subgroup (Kamlial and Chinji formations), Middle Siwalik Subgroup (Nagri and Dhokpathan formations) and Upper Siwalik Subgroup (Tatrot, Pinjore and Boulder Conglomerate formations).

The classification of Jammu Siwalik has been given by number of geoscientists (Ranga Rao et al., 1988; Gupta and Verma, 1988; Agarwal et al., 1993 and Gupta, 2000) from time to time and correlated it with standard classification of the Siwalik given by Pilgrim (1934). The comparative lithological classification of Siwalik Group of rocks in Jammu is given in Table-1. 


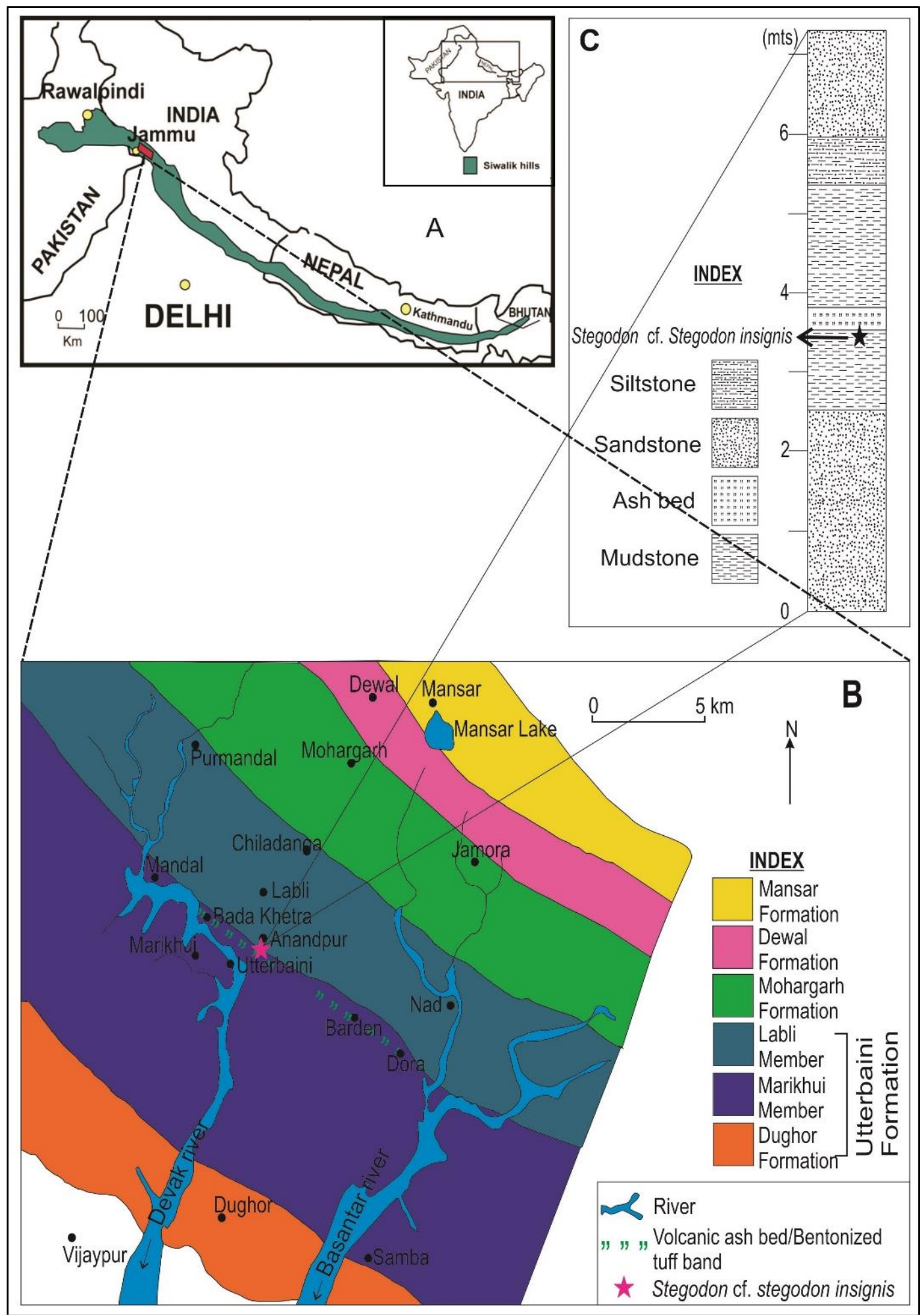

Fig. 1: A. Map showings disposition of Siwaliks in Himalayan foreland basin, B. Geological map of the study area showing Stegodon location, C. Position of Stegodon cf. Stegodon insiginis in the lithocolumn. 
A Late Pliocene Baby Stegodon cf. Stegodon insignis (Proboscidea) from Upper Siwalik of Samba District, Jammu and Kashmir, India: Kundal et al.

Table-1: Lithostratigraphic classifications of the Siwalik sequence of Jammu region

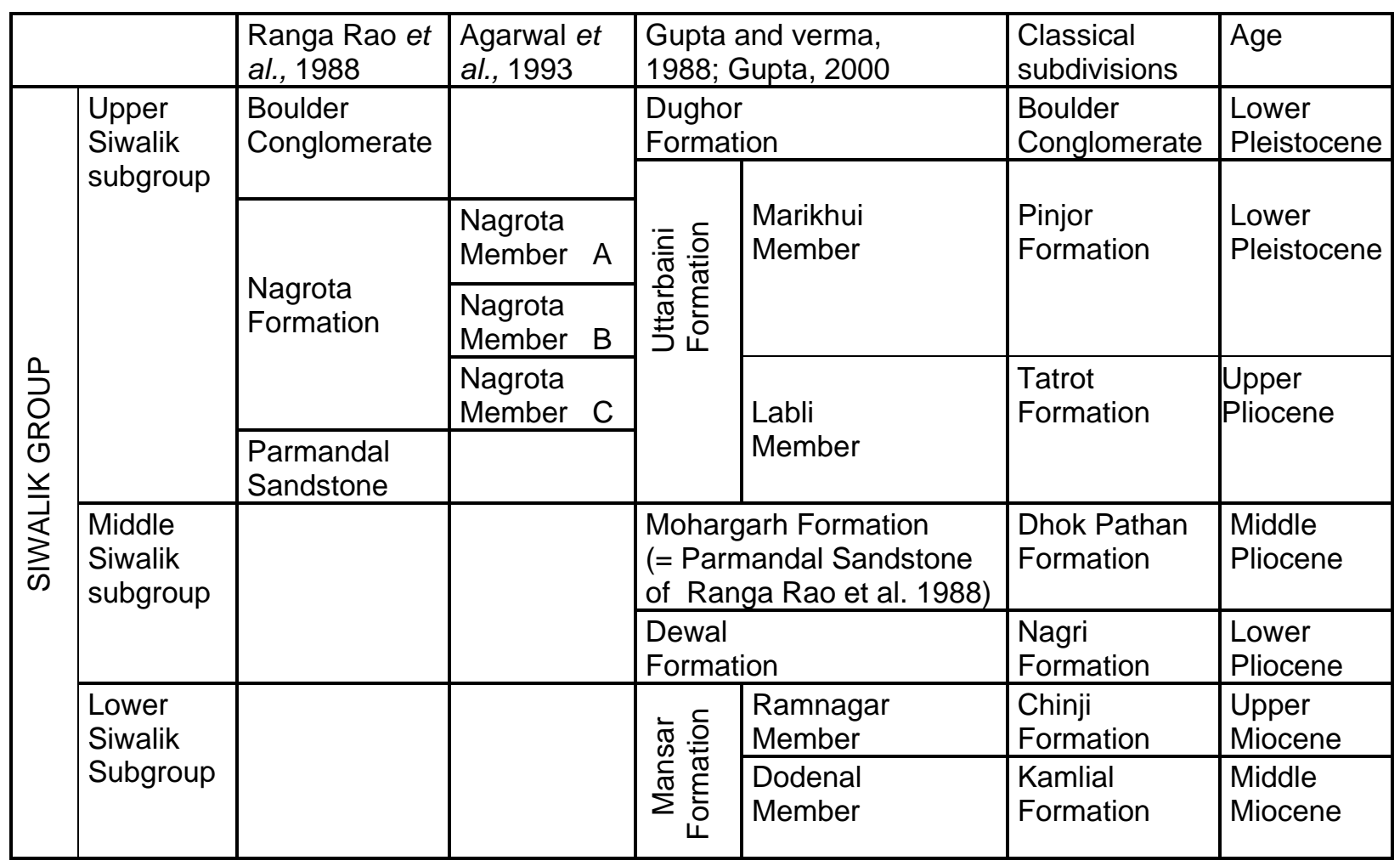

\section{SYSTEMATIC PALAEONTOLOGY}

Class Mammalia Linnaeus

Order Proboscidea Illiger, 1811

Family Elephantidae Gray 1821

Subfamily Stegodontinae, Osborn, 1918

Genus Stegodon Falconer \& Cautley, 1847

Stegodon cf. Stegodon insignis Falconer and Cautley, 1846

(Fig. 2 A-F)

Referred Material: JU/DG/VPL/9002, Upper right molar, $\mathrm{RM}^{2}$ complete molar.

Locality: near Anandpur village, district Samba, (Jammu and Kashmir). The section is about $2 \mathrm{~km}$ south of Labli village and $1.5 \mathrm{~km}$ east of Uttarbaini.

Horizon: Nagrota Formation (Ranga Rao et al., 1988)/ Uttarbaini Formation (Gupta and Verma, 1988) / Pinjore Formation (Pilgrim, 1934); underlying ash beds

\section{Age: Late Pliocene}

Measurements: length of molar $=110 \mathrm{~mm}$, width of molar $=60 \mathrm{~mm}$, length/width ratio of molar $=1.83$, number of ridges $=9$, average length of ridges (occlusal, lingual-labial) $=50 \mathrm{~mm}$, average width of ridges (occlusal, anterior - posterior) $=13.55 \mathrm{~mm}$, lamellar frequency (LF)= $8 \mathrm{~mm}$, average enamel thickness $(\mathrm{ET})$ of worn ridges $=2 \mathrm{~mm}$, average cement thickness (CT) between ridges $=8.83 \mathrm{~mm}$, average dentine thickness (DT) of worn ridges $=2.2 \mathrm{~mm}$, crown length $(\mathrm{CL})=110 \mathrm{~mm}$, Crown width $(\mathrm{CW})=50 \mathrm{~mm}$, maximum crown height $=55 \mathrm{~mm}$, hypsodonty Index $(H / W \times 100)=110$ 
Description: well preserved specimen consists of nine ridges. Each ridge consists of at least eight conelets. The conelets of anterior three ridges are worn out to form worn ridges. The molar curvature is straight and has parallel sides. The width of molar from the base of crown is greatest. The inclination of ridges to occlusal surface is weak. The valleys between the ridges are completely filled with thick cement and shows "V" shaped pattern. The roots of the molar are not well preserved. Many apical digitations in form of conelets were preserved. The complete enamel loop only preserved in worn plates. The specimen has neither anterior nor posterior columns, except in plate second which shows little bit strong posterior column. The molar height is more in the middle than at anterior and posterior ends. The conelets of each ridge is covered with thick cement and thickness of cement increases from anterior to posterior.

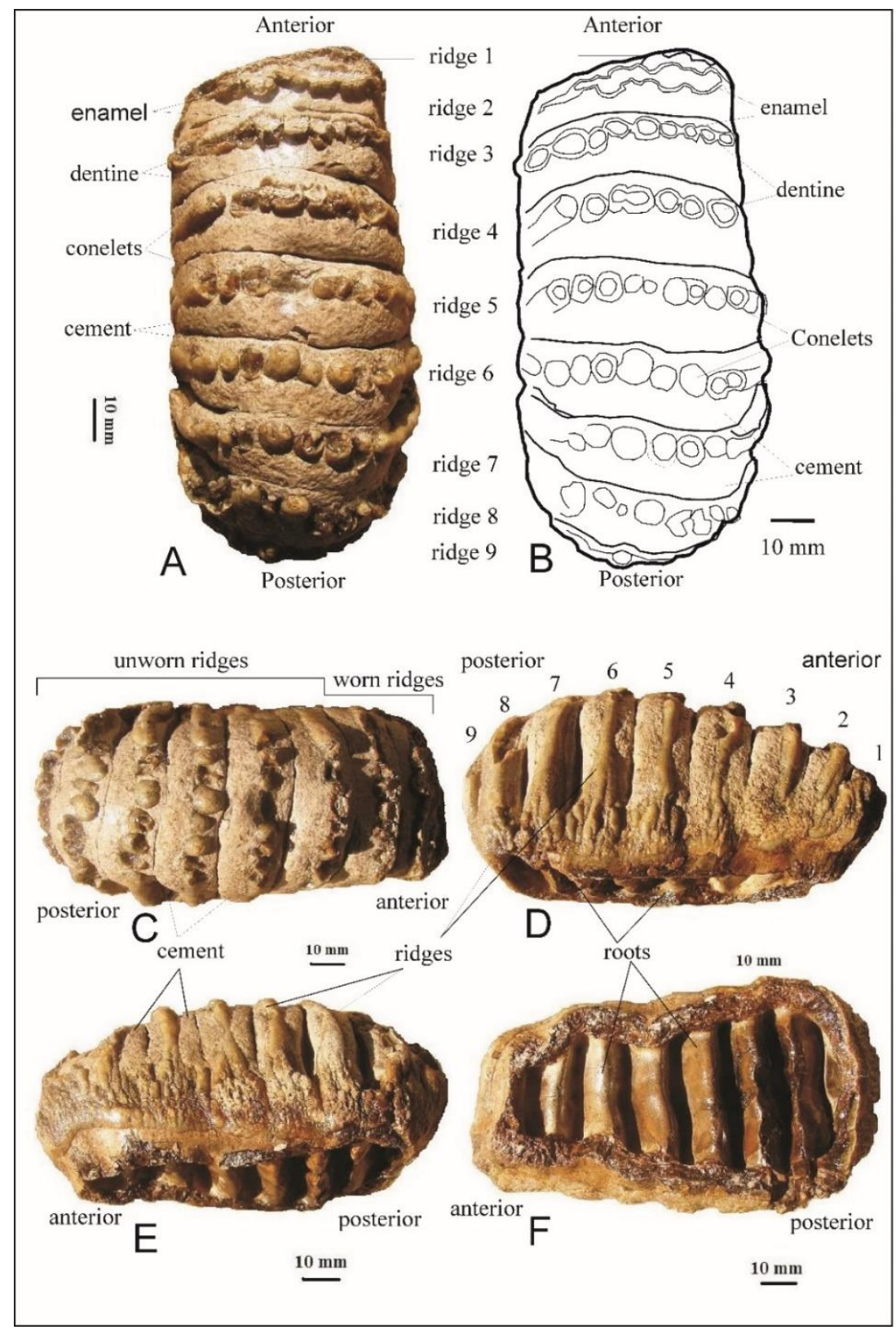

Fig. 2: Stegodon Molar: A. Occlusal View (Anterior-Posterior), B. Line drawing Occlusal view (Anterior-Posterior), C. Occlusal- lateral view, D. Labial-lateral view E. Lingual lateral view and $\mathrm{E}$. Roots view. 

given below:

The ridge wise description of JU/DG/VPL/9002 specimen from anterior to posterior is

Ridge first: Well worn plate with little bit broken anterior enamel. The length (lingual-labial) of the plate is $40 \mathrm{~mm}$ in occlusal view and width (anterior-posterior) is $4 \mathrm{~mm}$ the crown height above the roots is $22 \mathrm{~mm}$ and enamel thickness is $1 \mathrm{~mm}$. The thickness of cement between plates first and second is $3 \mathrm{~mm}$. This plate is distinct from other plates has it extends towards labial than other plates. This plate is the anterior most plate of the molar.

Ridge second: The plate has well exposed enamel, dentine and cement with small folds at the centre of plate in occlusal view. This plate is well preserved and worn out. The length of plate is $42 \mathrm{~mm}$ and width is $13 \mathrm{~mm}$. The crown height is $30 \mathrm{~mm}$ above the roots. The enamel thickness of plate is $2 \mathrm{~mm}$ and dentine thickness is $3 \mathrm{~mm}$. The cement thickness between plates second and third is $10 \mathrm{~mm}$.

Ridge third: Half worn plate consists of nine conelets. The three conelets from lingual side are broken while remaining conelets are exposed with enamel, dentine and cement. The plate is well preserved and shows folding at the centre towards lingual side. In occlusal view, the length (lingual-labial) of plate is $48 \mathrm{~mm}$ and width (anterior-posterior) is $14 \mathrm{~mm}$. The enamel thickness of this plate is $2 \mathrm{~mm}$ and average dentine thickness is $2.5 \mathrm{~mm}$. The plate has $35 \mathrm{~mm}$ crown height above the roots.

Ridge fourth: This plate consists of seven conelets. The conelets at the centre of plate are worn out but towards lingual and labial they are unworn. The dentine, enamel and cement thickness of worn conelets has been measured. The length (labial-lingual) and width (anterior-posterior) of worn conelets ridge is $50 \mathrm{~mm}$ and $15 \mathrm{~mm}$ respectively. The crown height above the roots is $48 \mathrm{~mm}$ and the enamel thickness is $2 \mathrm{~mm}$. the average dentine thickness of worn conelets ids $2 \mathrm{~mm}$ and the cement thickness between plates fourth and fifth is $11 \mathrm{~mm}$.

Ridge fifth: Completely unworn plate and consists of well preserved eight conelets. The diameter of unworn conelets various in size from $1.5 \mathrm{~mm}$ at the lingual and labial to $3 \mathrm{~mm}$ at the center of the plate. The length and width of the plate is $52 \mathrm{~mm}$ and $15 \mathrm{~mm}$ respectively. The crown height above the roots is $52 \mathrm{~mm}$. The enamel thickness and dentine thickness could not be measured as the conelets are not worn out. The cement thickness between plates fifth and sixth is $11 \mathrm{~mm}$.

Ridge sixth: Well preserved unworn plate with eight conelets. The diameter of conelets varies from $1 \mathrm{~mm}$ to $4 \mathrm{~mm}$. The length and width of plate is $55 \mathrm{~mm}$ and $12 \mathrm{~mm}$ respectively. The plate shows $56 \mathrm{~mm}$ crown height above the roots. The dentine and enamel thickness could not be measured as the conelets are not worn out. The cement thickness between plates sixth and seventh is $9 \mathrm{~mm}$.

Ridge seventh: Well preserved plate with eight conelets. Diameter of conelets various from 2 $\mathrm{mm}$ to $5 \mathrm{~mm}$. the length and width of plate is $57 \mathrm{~mm}$ and $13 \mathrm{~mm}$ respectively. The crown height of this plate is $57 \mathrm{~mm}$ and the thickness of cement between plates seventh and eighth is $9 \mathrm{~mm}$.

Ridge eighth: This plate consists of nine conelets. All the conelets are broken except two at the centre of plate. The diameter of conelets not properly measured but estimated maximum diameter is $4 \mathrm{~mm}$. The length and width of plate is $52 \mathrm{~mm}$ and $16 \mathrm{~mm}$ respectively. The maximum crown height of the plate above the roots is $42 \mathrm{~mm}$ and thickness of cement between plates eighth and ninth is $10 \mathrm{~mm}$. 
Ridge ninth: Plate consists of six broken conelets. The length and width of plate is $40 \mathrm{~mm}$ and $6 \mathrm{~mm}$ ( $+6 \mathrm{~mm}$ half broken posteriorly) respectively. The crown height above the roots is $32 \mathrm{~mm}$. Due to the broken occlusal surface of the conelets the dentine and enamel thickness could not be measured.

\section{COMPARATIVE STUDY WITH THE ALLIED SPECIES OF INDIAN SUBCONTINENT}

By using the dental morphological parameters (plate/ridge numbers, length, width and height of molar, enamel thickness, crown height, crown width, lamellar frequency, hypsodonty index, etc.) the specimen under study has been compared with the allied species of Stegodon (Stegodon bombifrons, Stegodon elephanttoides (cliftii), Stegodon pinrjorensis, Stegodon insignis biramanicus, Stegodon insignis, Stegodon ganesa) known from India, Pakistan and Burma from time to time by the palaeontologists. The Stegodon bombifrons differentiated from present specimen having nine and half plates or ridges and each plate consists of eleven or more than eleven conelets. Stegodon elephantoides (=cliftii) differentiated from specimen understudy having eight and half plate and each plate consists of ten or more conelets and each plate is not coated with thick cement. Stegodon pinrjorensis has eleven and half to thirteen plate or ridges, but the specimen under discussion have nine plate or ridges. Stegodon insignis biramanicus is differentiated from the specimen understudy having twelve to fifteen plate ridges and the plate ridges covered with thin cementing material. The specimen under discussion is also compared with the Stegodon insignis and Stegodon ganesa which may represent a female and a male respectively of the same species. $\mathrm{M}^{3}$ of Stegodon insignis has ten plates or ridges but the Stegodon ganesa has eleven plates or ridges and each ridge consists of eleven conelets. The present specimen is compared with Stegodon insignis-ganesa having nine plates or ridges and each ridge consists of eight conolets except last posterior plate of molar which have preserved six conelets and resembles Stegodon insignis- ganesa. Each plate of the present described specimen is coated with thick cement and the cement thickness increases from anterior to posterior which resembles with Stegodon insignis. On the other hand, the quantity of cement coating is less in case of Stegodon ganesa. As the specimen was a baby Stegodon so it has thin enamel figure, high lameller frequency and thick cement. Had it been an adult the dimension of the tooth would have been $330 \mathrm{~mm}$ and the corresponding enamel thickness of $6 \mathrm{~mm}$ and LF is 4 . Given this analogy of the specimen with an adult and its comparison with the specimen number 19801, right upper second molar at American Museum collected by Barnum Brown from Pinjor horizon (below conglomerates) three miles northeast of Siswan, Upper Siwalik India. After comparing the molar morphological parameters of JU/DG/VPL/9002, with all Indian Stegodon species, the specimen shows close affinity to Stegodon insignis and tentatively referred as Stegodon cf.Stegodon insignis Falconer and Cautley

\section{Age and preservation of recovered Stegodon specimen}

The specimen under study was recovered from the mudstone horizon underlying the geochronological dated (2.48 my) volcanic ash bed (Ranga Rao et al.,1988) exposed at Anandpur village which is the extension of Barakhetar-Uttarbehani ash bed. This volcanic ash bed is a time marker horizon in the Upper Siwalik and exposed in the Siwalik of Jammu at least in eighteen localities having same strike (East- West direction). Bhat et al. (2008) discussed the origin of these ash beds and established four palaeo-lakes within $45 \mathrm{~km}$ based on the facies study of ash bed and associated mudstone horizons. The associated mudstone horizons also preserved/contain a good assemblage of micro-fauna (ostracodes, gastropods, fishes, rodents) and flora (charophytes) species. The four established palaeolakes are 1. Dora-Karju Tiba, 2. Kherdi- stonywaste-Anandpur, 3. Uttar Behani - 
Barakhetar-Mandal, and 4. Khanpur - Kamini. These palaeo-lakes spreads in 2 to $7 \mathrm{~km}$ area and 5-6 km deep. The present collection is from the section of Kherdi-Stonywaste-Anandpur Palaeo-lake. As the elephants having habitat of living both in terrestrial as well as water bodies and spends sometime of their life in fresh water bodies. The recovery of specimen from the Kherdi-Stonywaste-Anandpur Palaeo-lake sections underlying the ash bed indicates that the death of Stegodon Cf. Stegodon insignis (specimen under study) might be due to the volcanic ash bed and the specimen preserved in the palaeo-lake sediments. The mudstone horizons underlying the ash bed are very rich in microfauna and flora than the mudstone horizon overlying the ash beds and also have different species. A good number of ichnospecies also collected within these ash beds. This indicates that the preservation might be due to spreading of ash fall deposits. Various author dated these volcanic ash beds from time to time (Yokayama et al., 1987, Ranga Rao et al., 1988, Agarwal et al., 1993), but the ash bed dated (2.48 m.y.) by Ranga Rao et al., (1988) may be reliable which is coincide with the Gauss-Matuyama boundary. This ash bed many author consider as equivalent to PlioPleistocene boundary in Indian Siwalik.

\section{Origin, migration and distribution of Stegodon}

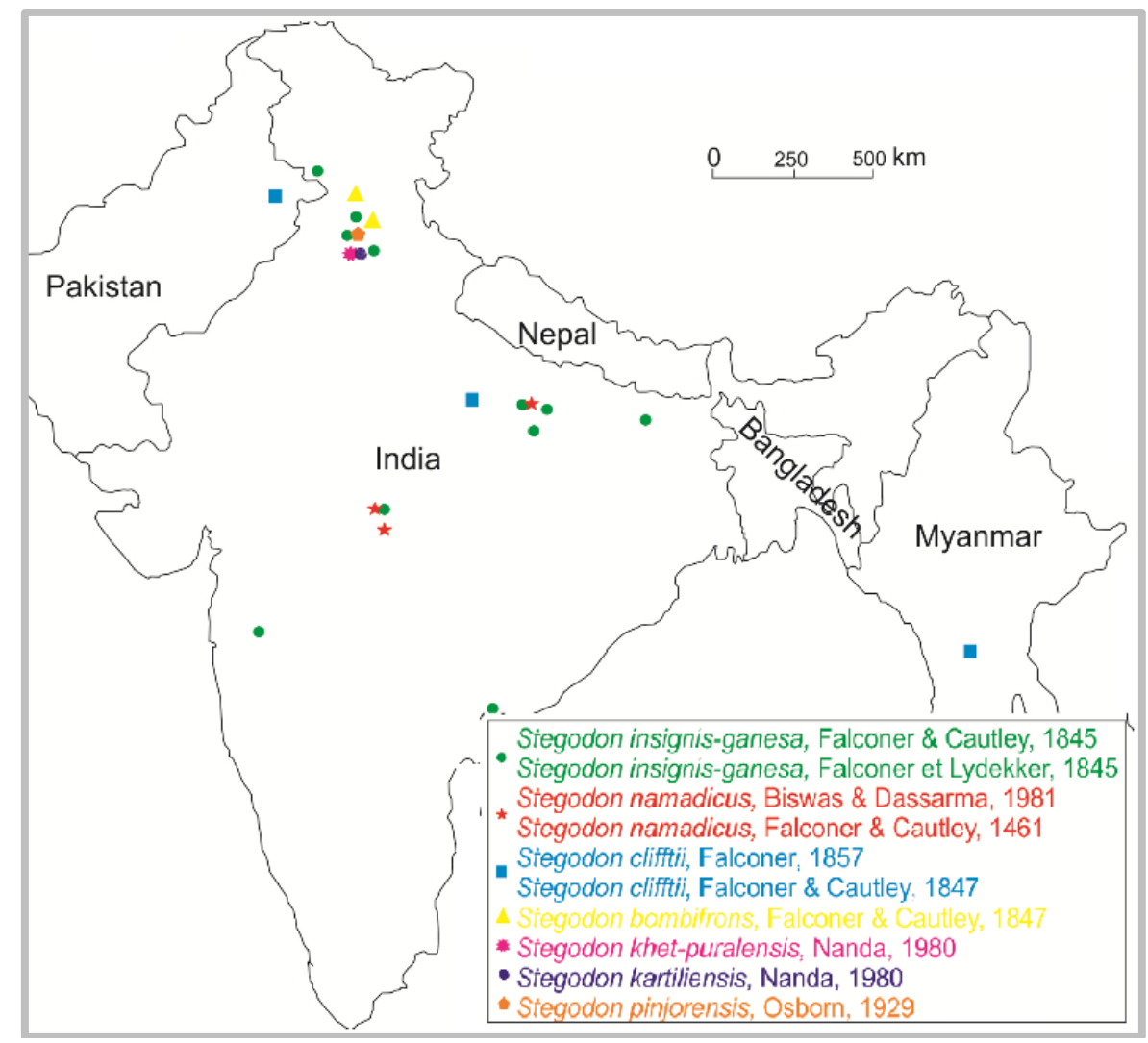

Fig.3: Distribution of Stegodon fauna recovered from the Indian subcontinent from time to time.

The origin of Stegodon is the topic of debate among the palaeontologists. Earlier it was believed that the Stegodon first originated in the Asian continent and migrated later to other continents. The earliest known Stegodon is from the northern China (upper Mauhi Formation) which was dated 5.5 to $6 \mathrm{Ma}$. At the same time the first appearance of Stegodon in the Western Rift valley and the Middle Awash having ages 4-6 Ma and 5.5 Ma 
respectively. However, the recent discovery of Stegodon from the geochronolically dated Mpsida beds (dated approximately 6.5 Ma) of Tugen Hills, Kenya may shift the place of origin of Stegodon from Asian continents to African Continent (Sanders, 1999). The general opinion of palaeontologists is that Stegondon was the species of Asian continent but a few authors are of the opinion that the central place of origin of Stegondon was Africa and later dispersed to the Middle East and Southern Asia. Based on the cladistic studies, the origin of Stegodon initially was African (Kalb et al., 1996) but the frequency of occurrence of Stegodontaxa in Africa was rare than the Asia. Stegodon licenti is the most primitive form from Asia and its dental characters have an intermediate position between Steglophodon pseudolatineds and Stegodon zydanski. Stegodon is the sister cousins of genus Steglophodon.

In Late Miocene-Early Pliocene, expansion of the Stegodon took place in Africa and the same time the Stegodon taxa were well flourished, phyllogentically diversified and abundant in Asia and became a dominant member of Asian fauna (Saegusa, 1996). The elephant fauna did not migrate from Africa until Middle Pliocene. The recovery of Stegodon with early elephant's fauna in South Africa implies that Stegodon and early elephants ecologically co-existed. Brachydonty type of molar in Stegodon indicates browsing or mixed type of feeding in forest environment (Janis, 1986). The disappearance of the Stegodon from African continent was due to significant increase in C4 biomass during the Late Pliocene. In Indian subcontinent the oldest record of the Stegodon (Stegodon clifti) from the Dhokpathan Formation (Potwar/ Hasnot), Middle Siwalik, Pakistan. The distribution of Stegodon fauna recovered from the Indian subcontinent by authors from time to time is given in the Fig.3.

\section{CONCLUSION}

The Stegodon cf. Stegodon insignis (baby) recovered from the mudstone horizon underlying the geochronological dated (2.48 my) volcanic ash bed at Anandpur section which is the extension of Barakhetar-Uttarbaini section indicates that the specimen is not younger than ash bed. As the Anandpur section was the marginal part of the Kherdi-Stony waste - Anandpur palaeo-lake and the recovery of Stegodon underlying the ash bed indicate that the death might be due to ash fall.

Acknowledgement: The corresponding author is thankful to SERB, New Delhi for financial support under SERB project (SR/FTB/ES-71/2013). The corresponding author also thankful to Dr. V. P. Mishra, Dy. D. G. (Retd.), G.S.I. for reviewing the manuscript.

\section{REFERENCES}

Agarwal, R. P., Nanda, A.C. Prasad, D.N., and Dey, B.K. (1993) Geology and biostratigraphy of the Upper Siwalik of Samba Area, Jammu foothills. Him. Geol, v.4 (2), pp.227-236.

Aguirre, E. (1969) Evolutionary History of the Elephants. Science, v.164(3886), pp.1366-1376.

Ann (1985) Discovery of Two Stegodon ganesa tusks found in the Tatrot Horizon near Nagrota, Himachal Pradesh. Geol. Surv. India., Northernt Region Newslett., v. 5(2), pp.7.

Arif, M. and Hussain, S.T. (1992) Upper Siwalik vertebrate faunal correlations in Sub-Himalaya. Geol. S. Asia I (Proc. first S. Asia Geol. Congr., Islamabad, Pakistan), pp.102-105.

Badam, G.L. and Sharma, S.P. (1973) Observations on a milk dentition of Stegodon insignis (Falconer and Catuley) collected from the Upper Siwalik around Chandigarh. J. Univ. Poona (Sci. Tech.), v.44, pp.165-173.

Badam, G.L. and Salahuddin (1982) Some new fossil sites on the central Narmada Valley, Madhya Pradesh, India. Curr. Sci., v.51 (18), pp. 898-899. 
A Late Pliocene Baby Stegodon cf. Stegodon insignis (Proboscidea) from Upper Siwalik of Samba District, Jammu and Kashmir, India: Kundal et al.

Badam, G.L. and Kumar, A. (1982) Fossil Proboscidea from the Siwaliks of Raipur Rani, Ambala, Hayrana. Bull. Deccan Coll. Res. Inst., India. Off prints, v.41, pp.1-10.

Bhandari, A. and Kundal, S. N. (2008) Ostrocodes from the Nagrota Formation, Upper Siwalik Subgroup, Jammu, India. Rev. Espan. Micropalaentol., v.40(1-2), pp.151-166.

Bhat, G.M., Kundal, S.N. and Prasad, G.V.R. (2008) Depositional origin of tuffaceous units in the Pliocene, Upper Siwalik Subgroup, Jammu (India), NW Himalaya. Geol. Mag., v.145(2), pp. 279-294.

Chakravati, D.K. (1965) A geological, palaeontological and phylogenetical study of the elephantoidea of India, Pakistan and Burma. Part II: elephantoidea, D.N. Wadia Commemorative Vol. Mining Geol. Metall. Inst., India, pp.255- 272.

Falconer, H. and Cautley, P.T. (1846) Fauna Antiqua Sivalensis, Part I, Proboscidea: Smith, elder and Co., London.

Falconer, H. and Cautley, P.T. (1846-49) Fauna Antiqua Sivalensis, being the fossil zoology of the Sewalik Hills in the North of India, Smith, Elder and Co., London

Falconer, H. (1857) On the species of mastodon and elephant occurring in the fossil state in Great Britain, Part I, Mastodon: Quat. J. Geol. Soc. London, v.13, pp. 307-360.

Ganjoo, R.K. (1985) Some new fossil proboscidea from the Siwalik of Jammu. Ctr. Adv. St. Geol., Punjab Univ., Chandigarh, v.1, pp.177 - 184.

Ganjoo, R.K. (1992) On the evolution of the Pleistocene elephants in the Indian Subcontinent and their ecological Implications. Islamabad, Pakistan. Proc. First S. Asia Geol. Cong. (Geol. S. Asia), v.1, pp.46-51.

Gray, J.E. (1821) On the Natural Arrangements of Vertebrate Animals, London. Med. Reposi., v.15, pp. $296-310$.

Gupta, S.S. and Verma, B.C. (1988) Stratigraphy and vertebrate fauna of the Siwalik Group, MansarUttarbehani Section, Jammu District, Jammu and Kashmir. J. Palaeontol. Soc. India, v.33, v.117-124

Gupta, S. S. (2000) Lithostratigraphy and structure of the Siwalik succession and its relationship with the Muree succession around Ramnagar area, Udhampur District, Jammu and Kashmir. Him. Geol., v.21, pp. 53-61.

Hooijer, D. A. (1955) Fossil Proboscidea from the Malay Archipelago and India. Zool. Verhandel., v. $28,146 \mathrm{p}$.

Hooijer, D. A. (1964) Pleistocene vertebrates from Celebes: XII. Notes on Pygmy Stegodonts. Zool. Meded., v.40(7), pp.37-44.

Illiger, C. D. (1811) Prodromussystematis mammaliumet avium additis terminus. Zoogr. Uttriusque Classis. Salfeld Berlin, 301p.

Janis, C.M. (1986) An estimation of tooth volume and Hypsodonty Indices in ungulate mammals and correlation of these factors with dietary preference, In: D.E. Russell, J.P. Santoro and D. Sigogneau-Russell (eds.), Teeth Revisited: Proc. VIlth Int. Symposium on Dental Morphology, Paris. Memories Mus. Nat. d' Historie Naturellie, Paris, ser. C, v.53, pp. 367-387.

Joshi, R.V., Badam, G.L. and Pandey, R. P. (1982) Fresh data on Quaternary animal fossil and stone age cultures from the central Narmada Valley, India. Asian Perspective, v.21(2), pp.164-181.

Kalb, J.E., Froehlich, D.J. and Bell, G.L. (1996) Palaeobiogeography of Late Neogene African and Eurasian Elephantoideapp. In: J. Shoshani and P. Tassy (eds.) The Proboscidea, evolution and palaeoecology of elephants and their relatives. Oxf. Univ. Press, Oxford. pp. 117-123.

Kundal, Y.P. and Kundal, S.N. (2011) Elephas cf. E. maximusindicus (Elephantidae, Mammalian) from the Post Siwalik Deposits of Jammu Province, Jammu and Kashmir, India. Vert. Pal. Asiat., v.49 (3), pp. 348-361. 
Kundal, S.N. and Prasad, G.V.R., (2011) ? Late Pliocene-Early Pleistocene micro-vertebrates from the Upper Siwalik Subgroup of Jammu, Jammu and Kashmir, India. Earth Sci. India, v. 4(3), pp.143-158, http://www.earthscienceindia.info/

Kundal, S.N. (2012) Micro-biotic composition of Nagrota Formation Upper Siwalik Subgroup of Jammu, Jammu and Kashmir, India. Int. J. Curr. Res., v.4(12), pp.60-65, http://www.Journalcra.com

Kundal, S.N. (2013) Late Pliocene (Piacenzian Stage) fossil molluscs from Upper Siwalik Subgroup of Jammu, Jammu and Kashmir, India. Int. Res. J. Earth Sci., v.1(4), pp.10-17, www.isca.in

Kundal, S.N. (2015) Microfossils based palaeoecology and palaeocommunity structure of Upper Siwalik deposits of Jammu, Jammu and Kashmir, India. Int. Res. J. Biol. Sci., v.4(1), pp.3440, www.isca.in

Kundal, S.N., Bhadur, G. And Kumar, S. (2017) Elephas cf. E. planifrons (Elephantidae, Mammalia) from Upper Siwalik Subgroup of Samba district, Jammu and Kashmir, India. Vert. Pal. Asiat., v.55, pp.59-70.

Lamba, V.J.S. (1993) Occurrence of giant Stegodon tusks from Narmada valley, India. Curr. Sci., v. 64(3), pp.149-150.

Maglio, V. J. (1973) Origin and evolution of the elephantidae. Trans. Am. Phil. Soc., v.63 (3), pp.1145.

Nanda, A.C. (1988) A new species of Stegodon from the Upper Siwalik Subgroup of Ambala, India. Geol. Surv. India, Spec. Pub., v.11(2), pp.365-370.

Nanda, A.C. (1980) A new species of Stegodon from the Upper Siwalik Subgroup of Ambala, India. Geol. Surv. India, Spec. Pub., v.2(11), pp.365-370.

Nanda, A.C. and Corvinus, G. (2000) Skull characterstics of two Proboscideans from the Upper Siwalik Subgroup of Nepal. Neues Jahrb. Geol. Paläontol./ Abh., v.217, pp.89-110.

Nanda, A.C. (2015) Siwalik mammalian faunas of the Himalayan foothills with special reference to biochronology, linkages and migration. Wadia Inst. Him. Geol. Monograph, Ser. 2, pp.1-241.

Osborn, H.F. (1918) A long jawed mastodon skeleton from South Dakota and phylogeny of the Proboscidea (Abstract). Bull. Geol. Soc. Am., v.29, pp.133-137.

Pilgrim, G.E. (1934) Correlation of fossiliferous section in Upper Cenozoic of India. Am. Mus. Novit., v.704, pp.1-5.

Prasad, G.V.R., Kundal, S.N. and Bhat, G.M. (2005) Mandible of Golunda (Rodentia, Mammalia) from the Upper Siwalik Subgroup of Jammu, India. Ann. Paleontol., v.91, pp.81-196.

Rai, Y.C. (2004) Fossil elephants from the Indian subcontinent and their tusks: A review. J. Paleontol. Soc. India, v.49, pp.169-188.

Ranga Rao, A., Agarwal, R.P., Sharma, U.N., Bhalla, M.S. and Nanda, A.C. (1988) Magnetic polarity stratigraphy and vertebrate paleontology of the Upper Siwalik Subgroup of Jammu hills, India. J. Geol. Soc. India, v.31(1), pp.361-385.

Saegusa, H. (1996) Stegodontidae: evolutionary relationships. In: J. Shoshanio and P. Tassy (eds.), The Proboscidea. Evolution and palaeoecology of elephants and their relatives. Oxf., Univ. Press, Oxford, pp.178-190.

Samiullah, K., Akhtar, M., Yasin, R., Sultana, S., Naeem, S., Mushtaq, S. and Nasim, S. (2014) Proboscidean fossil fauna from the Siwalik hills of Pakistan. $6^{\text {th }}$ International conference on mammoths and their relatives. Sci. Ann. School Geol., Spec. Abst. Vol.102, pp.176- 177.

Sanders, W.J. (1999) Oldest record of Stegodon (Mammalia: Proboscidea). J. Vertebr. Palaeontol., v.19(4), pp.793-796.

Sahni, M. R. and Khan, E. (1961) On a complete dentition of a young Stegodon insignis (Falconer and Cautley). Res. Bul., Punjab Univ., v.12, pp.259-261. 
A Late Pliocene Baby Stegodon cf. Stegodon insignis (Proboscidea) from Upper Siwalik of Samba District, Jammu and Kashmir, India: Kundal et al.

Tobien, H. (1977) Migrations and non-migrations of Proboscideans (Mammalian) via Bering Strait land bridge in the Late Cainozoic. J. Paleontol. Soc. India, v.20, pp.237-243.

Verma, B. C., Mishra, V.P. and Gupta, S.S. (2002) Pictorial catalogue of Siwalik vertebrate fossils from Northwest Himalaya. Geol. Surv. India, Cl. Ser. no. 5, 1-378 p.

Wadia, D.N. (1925) Stegodon ganesa in the outer Siwalik of Jammu. Rec. Geol. Surv. India, v.56, pp. $352-355$.

Yokoyama, T., Verma, B. C., Mastuda, T., Gupta, S. S. and Tewari, A.P. (1987) Fission-Track age of a bentonitized ash bed and mammalian fauna from Nagrota Formation (Upper Siwalik) of Jammu District (J \& K), India. Indian Mineral., v.41 (4), pp.13-23.

(Received: 07.06.2017; Accepted: 13.7.2017) 